\title{
CONCEPT OF HUMAN SECURITY AS AN ANALYTICAL FRAMEWORK FOR DETERMINING THE INTERNATIONAL POSITION OF A SMALL STATE
}

\author{
Zeljko Ivanis, PhD \\ Faculty of Security Studies, University of Belgrade, Serbia \\ E-mail: landol@eunet.rs \\ Ivica Djordjevic, $\mathrm{PhD}$ \\ Faculty of Security Studies, University of Belgrade, Serbia \\ E-mail: djivica@gmail.com
}

Abstract: The state as an organized system of institutions that should represent the interests of its citizens significantly changes the position in terms of globalization. The territory, population and sovereignty as the three basic elements of statehood take on new characteristics with the development of global processes. The main features of globalization: the porosity of national borders, the liberalization of trade and migration of people, and the expansion of business networks influence the position of modern states. Large and developed countries still manage to keep control over the basic levers of national power, while the territorial integrity of small, underdeveloped countries is under a big question mark.

The complexity of current global conditions requires a new approach in the process of analyzing the factors that influence the international position of countries. We believe that the seven-dimensional model of the concept of human security can contribute to the quality of the analysis of internal situation impact on the international position of national states. The correlative connection of human security status indicators in the territory of a state with its international position, it can be most easily perceived in the example of so-called weak states.

Keywords: international position, globalization, human security concept, national power, status indicators 


\section{Introduction}

With the globalization of economic activities many classical concepts of international relations require a review and introduction of new parameters into the analysis. International relations based on the UN system stemming from the agreement of the great powers who won in World War II are shattered from the ground. Global networks of transnational economic subjects with uncontrolled capital flows seriously alter the Westphalia order based on the sovereignty of states. In the given circumstances, many questions regarding the layout of newly created environment open up. The subject of this study represents an attempt to analyze the position of a small state in the new context created by globalizing human activities. One of the possible approaches is the analysis of the international position of small countries based on the seven-dimensional matrix of concept of human security. Namely, the concept of human security as an analytical framework that focuses on the security of citizens in the conditions of globalization provides elements for the analysis, which can largely explain the current situation and identify the factors that determine the international position of a small state. It is essential to an approach that a state is viewed as the unity of territorial characteristics, demographic characteristics and efficiency in the functioning of institutions that should the interests of its citizens.

The international position of a state is a complex issue. Its dimensions pertain to the past, present and future, and on issues of vital interest: security, independence, territorial integrity... Each of these periods is determined by its specifics that need to be taken into account. Consideration of the international position of the state requires a comprehensive analysis of all factors relevant to the determination of the causes and consequences of specific events. Finding answers to questions about the international position of a country requires the involvement of all relevant elements. Determining the meaning of the basic concepts is essential in order to avoid misunderstandings in the approach, which we promote. The purpose of this paper is to point out the factors, which individually or in various combinations must be materials from which the real image (assessment, analysis) of the international position of a small country is made. We believe that the internal situation is at least as important as the global circumstances are for the evaluation of a small country international positioning. 


\section{Securitity}

Due to the value of their $\mathrm{GNI}^{1}$, the big and developed countries can still provide for the sufficient funding of their armed forces. Military power is directly proportional to the budget funds, and they depend considerably on the scope of business activities, influenced among other factors by political power that in turn stems from the scope of economy. Small and underdeveloped countries are facing a drop of the $\mathrm{GNI}$, thus lacking the funds for state functions. The position of small countries on the global power chart depends on the wholeness of local state of affairs and the motivation of their citizens to defend the interests of the community they belong to. The perception of actual situation in a given area and the projection of the future trends are possible by way of the analysis of factors that affect the quality of life of the locals. The human security concept enables for a qualitative analysis of the actual state of affairs through the stability of the system that depends on the quality of life of the citizens. Stability of the set of circumstances in the geographic area of a state directly reflects in its perception in international business circles, but also determines the geo-political actor perception of the territory in question. $^{2}$

\section{Concept of Human Security}

The essence of the concept of human security, shown in the UNDP Human Development Report of 1994, is best seen in the following quote: "The feeling of insecurity most people have comes over everyday concerns more than from fear of cataclysmic world events. Will they and their families have enough to eat? Will they lose their job? Will they be harassed

\footnotetext{
${ }^{1}$ Gross national income (GNI) is defined as the sum of value added by all producers who are residents in a nation, plus any product taxes (minus subsidies) not included in output, plus income received from abroad such as employee compensation and property income. The definition is taken from the site of the World Bank: http://data.worldbank.org/indicator/NY.GNP.PCAP.PP.CD 18.XI 2015.

${ }^{2}$ The point is that small countries do not have the capacity to develop a defense force that would be able to stand against the armies of big countries. In their strategies, small countries can plan the defensive actions that would deter potential aggressors because of the losses that would be exhibited. In the absence of technical potential, small countries can rely on the quality of the human factor, which depends, inter alia, of, motivation of citizens to fight in order to protect the interests of the community to which they belong. The motivation depends mostly on the life satisfaction of citizens within the framework of the state to which they belong, in this sense; the concept of human security provides the ability to analyze the most important elements on which the quality of life of citizens in the territory of a state depends.
} 
by the repressive state? Will they become victims of violence because of their commitments? Will they be the target of persecution due to their religious or ethnic background? ... In the final analysis, human security is a child who is not deceased, a contagious disease that has not spread, a job that is not denied, ethnic tension that does not explode in violence, and a dissident who is not silenced. Human security is not a problem of arms - it is a problem that concerns human life and dignity "(UNDP 1994: 22).

Bearing in mind the relationship: the citizens - the state i.e. the fact that the state emerges as a form of organization of people in a certain territory with the intention to realize their interests, it is very important to analyze the position of citizens and their satisfaction with the functioning of the system of state institutions in any analysis of the situation in the territory of a country and its place in the international arena. The concept of human security in a given context provides an analytical framework that allows the analysis of the quality of life that is based both the analysis of the quality of life that is based both both the analysis of the quality of life that is based both on objective indicators, as well as the subjective experience of the position of its citizens. Satisfied citizens are willing to fight for the interests of the community and maintaining the integrity of the territory regardless of the ethnic structure of the population. In countries where the social situation is unsatisfactory, causing instability and threatening community safety is possible in spite of a homogeneous composition of the population. In dysfunctional countries, it occurs that citizens who are dissatisfied with their lives and / or harassed by the government abandon the same and become political and / or economic migrants.

The authors of Human Development Report for 1994 list the following seven areas of importance for the determination of the status of security and/or insecurity in an area (UNDP 1994: 24-25):

1. Economic security,

2. Food security,

3. Health Security,

4. Environmental security,

5. Personal security,

6. Community security, and

7. Political security. 


\section{Security}

Each dimension of security listed above contains number of indicators that allow for the analysis of each dimension separately. Based on the results of the analysis it is possible to predict the trends of development of the situation and to respond appropriately in order to avoid possible crisis scenarios.

Global trends after the fall of the Berlin Wall are anticipated in the UNDP report for 1994 (UNDP, 1994). The aforementioned report offers a new analytical framework in order to contribute to a better understanding of the situation encountered and possible resolution of existing problems. The collapse of institutions, uncontrolled wandering of transnational capital, and proliferation of crime and the general decline of population life standard are becoming common features of transition countries during the $90 \mathrm{~s}$ of the last century. The removed Iron Curtain reveals a harsh reality, which shows that most of the problems of modern humankind are present in most people regardless of their ethnic, religious or any other affiliation. In this context, the UNDP report for 1994 presents the concept of human security, which draws attention to the problems of the global community in the making. Noting the essential elements of the status of citizens, we can simultaneously identify the factors that affect the position of small countries. Nation state institutions are the ones that create the ambiance not only in the geographic area that is under their jurisdiction, they also affect global flows.

Consideration of the status of individuals as members of the community of whose ambiance perception depends the contribution to the protection and realization of their interests is particularly important in the context of national power. The national power is defined as the ability of the state to influence the behavior of the relevant entities in accordance with its objectives and interests. (Mijalkovski and Đorđević, 2010: 3)

The elements of national power in many of its parts overlap with the dimensions of human security (Diagram 1). The status of human security in an area is determined by the degree of national power and success rate of its control mechanisms. The degree of unity between citizens and power holders (decision makers in the system) determines the position of the state in the international arena. Alienated power centers are a source of instability both at the national and global levels. 
Diagram 1: Factors of national power

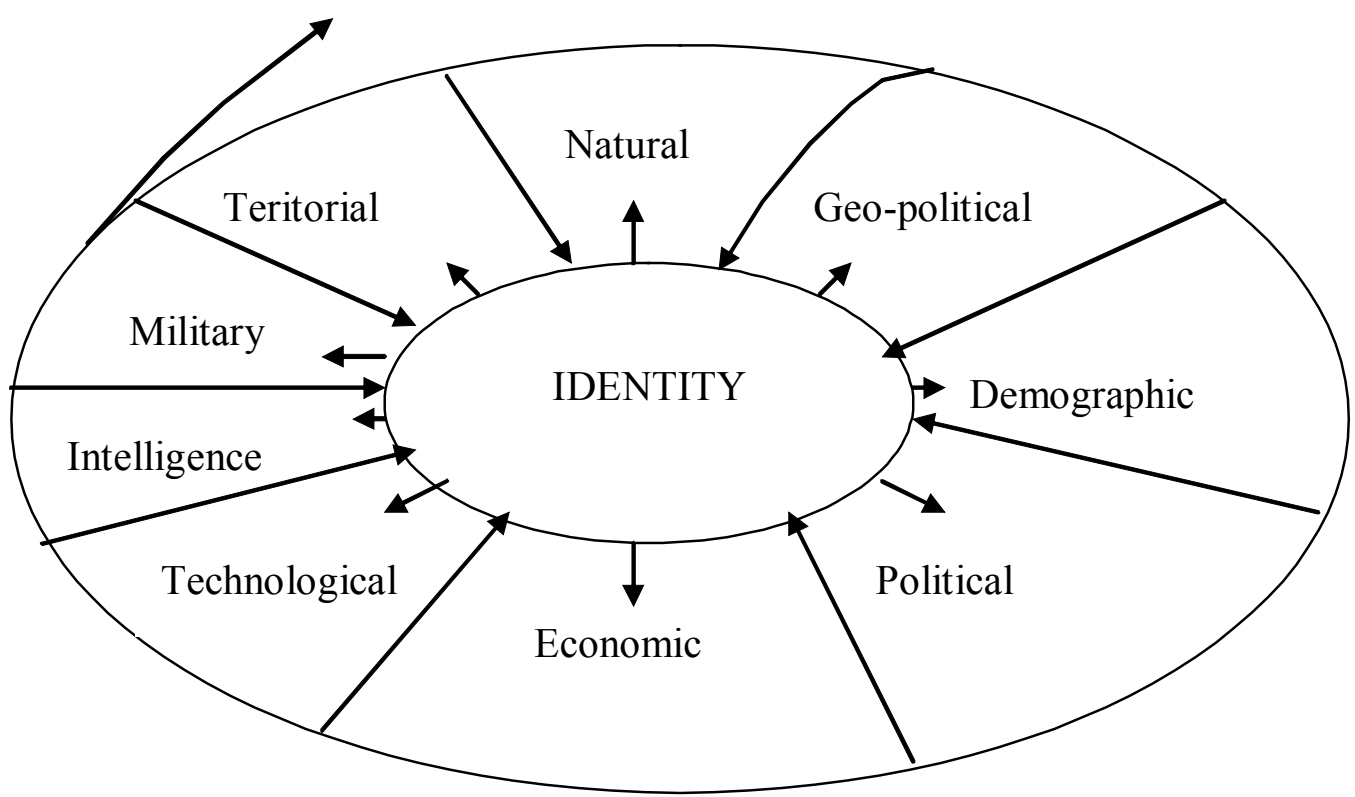

Source: Milan Mijalkovski, Ivica Đorđević: Neuhvatljivost nacionalne moći, Belgrade, Službeni Glasnik, 2010, p. 31.

In Diagram 1, we can see that the identity of members of the community (members of nations and state subjects) has a central position in the structure of national power. The condition of other centers of power the source of which is of internal origin depends on a sense of belonging to a community that lives in a certain area (state territory). Man as a factor in decision-making and implementing decisions largely determines the nature of the system, its resilience and ability to change for the better. Altruism of people and their awareness of the social role mean more than the amount of money in the form of compensation for performing certain tasks. Communities that through the system of education and upbringing succeed in reaching a level of collective awareness on which it is 
morally not acceptable to build individual status and prosperity on the exploitation and oppression of other members of society create the best institutional systems (e.g. Scandinavian countries).

\section{Elements of the analysis of international position of the state}

From the time of their first occurrence, the states engage in mutual relations. The character of these relations depended (and still depends) on the interest that refers a territorial community such as a state to another state and can range from conflict to cooperation. A certain relationship is inevitably established even if there is complete indifference between states. Self-isolation or isolation of one country by other countries also points to the fact that there is some relationship between them. Accordingly, each State has its "place" in the coordinate system of international relations, which is usually referred to as international position.

The state as an international entity is the basic element of reality called international relations (Dimitrijevic and Stojanović, 1979: 81-139). Under the term international relations, we assume the totality of links between "domestic" and "foreign" the two being separated by the state border. The term "international position" not only expresses the spatial coordinates of the territory in question, it determines the international situation in which an entity is. The international position of a state presents "its general position in the international community, which is the result of the interplay of all types of external and internal factors that influence, in a positive or negative sense, its internal development, its foreign policy and in particular the position and character of relations with other states, especially with neighboring countries and great powers "(Gavranov and Stojkovic, 1972: 312). In short, we can say that the international position of the state is its general position in the international community, which a state achieves in relations with other states, peoples and movements as well as political, economic, cultural, military and other organizations and associations.

\subsection{Factors of the international position of the state}

International life has its chronological tables. In some parts, they are richer in content than in some others. This speaks about an unequal flow of international relations. In the modern era, the process of interdependence of international subjects is so dynamic that the phenomena in the field of so-called internal relations in the strict sense affect at 
least some of the segments of international relations. First and foremost on the bilateral and often at the multilateral level.

In one part of the literature on the international relations, the term "factor" (factors) includes all relevant definitions of a phenomena falling within the framework of international life of countries. Other authors distinguish subjective from objective factors. A number of authors replace the word "factor" with the word "agent ", without any deeper consequences, or use those two words interchangeably. There are also a certain number of authors who call subjective factors: subjects and others they call: factors, and there are a number of those who both agents and factors from the previous versions call simply: factors.

The significance of each of these aspects of the international position in the aforementioned context is not easy to determine, because it is under the influence of "emitted power" of a large number of various factors. These factors are many even when only those of greater importance, also called basic, are listed: location, relief, natural wealth, population, socio-political and economic system, internal stability of the system, the level of development (economic, cultural and political) historical development and traditions, national defense system and its efficiency, general state of affairs in the world (political, military and economic), the status of relations between the great powers and military-political alliances, the character of relations with countries in the immediate region, the general level of development of science and technology in the world, the level of development of military technology, international law, international markets, international organizations, etc.

With regard to the essential characteristics of features by which they bear the names, all factors of the international position can be divided into geographical, political, economic, military, legal, demographic, scientific, technological, cultural, psychological, environmental, etc. Rather these are groups of factors. If we do not intend to analyze any aspect of international position or this position in its entirety using such classified factors because, for example, we do not require a detailed analysis, we may proceed with a different classification of the factors. We can use determinants. They provide a greater possibility of the synthetic approach to the position that we are investigating. In this sense there exist the following determinants: internal and external (based on the relation to the state border of the studied state); historical and contemporary (based on the time relationship to the point of studying); natural and social (based on factors belonging to 
the natural or social phenomena); permanent and variable (based on factor variability), etc. (Gavranov and Stojkovic, 1972: 237-240).

If we give the name: internal determinants to all the factors that determine the structure of a given state, and the name: external determinants to other considered factors, we can say that the international position is the function of changes within these two groups of factors. That is why we say that the international position is the dependent variable, and the determinants are its causes, i.e. the independent variables. Mathematically this could be expressed as $R=f(D u, D s)$, where $R$ is the reaction. It is the function of the internal (Du) and external (Ds) determinant actions. Thereby it should be known that not all factors are equally important from the standpoint of analysis of the international position. Some are quite insignificant in that sense. The relevant should also be distinguished from one another. Therefore, we consider one primary and the other secondary. Of course, the division of all factors may be made according to some other criteria.

The change of situation always precedes the change of position. In most cases, this is easy to perceive. Sometimes, however, it seems that this temporal relationship is disrupted. Analyzing the existential sense of the connection between cause and effect is determined that the first must have lower and the other higher absolute value on the time axis. However, this does not mean that the international position is only susceptible to influence. It is not a "passive" state. Its change at any time causes a chain reaction that is felt at the national level in the country concerned, in its foreign policy, relations with other countries and so on.

\section{Analysis of the international position in relation to the dimensions of human security}

Supporters of the classical school of international relations who observe the international position through a prism of military power and geopolitical parameters would base their analysis primarily on the classical elements of force, which determines the degree of realization of interests, in other words, the protection that others do not realize their own interests to the detriment of the observed entity. However, this approach, as already said, explicates the situations related to big, developed countries, capable of having numerous armed forces and innovative military technology. As opposed to that, the power of small and underdeveloped countries depends primarily on the willingness of citizens to participate actively in the defense of the interests and values of the community they 
belong to. In the given context, we can say that the status analysis based on the seven dimensions of human security in an area provides a number of elements sufficient to assess the state of national power of a state. With that, we can get the answers to the questions related to determining the geopolitical position of a small state. It also should be borne in mind that indicators relating to internal situation are used in the process of making the status analysis of human security, but their values also largely depend on external factors.

\subsection{Indicators of economic security as a function of analysis of the international status of a country}

The status of economy in a given area is critically important for the analysis of its stability and influence this territory has on the surrounding. However, a real perception of economic factors requires their placement in social and historical context of the subject of analysis. Whether it is a former colony or a metropolis, whether the population is of Muslim, Christian or some other religion is not all the same. Introducing parameters related to the wider area (region) in the plans of the great powers makes the analysis more complete. Only after setting the said analytical framework can we get reliable results of the analysis of economic conditions and their impact on the security of citizens, and indirectly to the international position of their state. Consideration of economic conditions in an area in terms of human security requires a complex multivariate analysis. It is not enough just to present national statistics on the movement of gross domestic product (GDP), or total income (GNI), their qualitative analysis is necessary. In addition to classic statistical data on production volume per capita, it is imperative to detect its structure and trends change. It is important to perceive to what extent the classical industrial manufacturing, ICT, and new technologies (bio and nano) are represented respectively. These data may indicate the current structural problems, and project future trends. They may show the extent to which the economy of a country adapts to current tendencies, and whether it succeeds in achieving (or maintaining), it is competitiveness in terms of globalization or is on a downward path.

Trying to isolate specific economic factors, it seems reasonable to stress the importance of economic development of countries. Under the term development, we mean qualitative changes in the economic structure that lead to growth in the volume of material production and services. However, we should be aware of the fact that not every growth is development simultaneously, but only the growth that contributes to improving the 
quality of life of citizens. In this respect, the possibilities of impact of this factor on the international position of the country are without a doubt. Most often in practice a high level of economic development means that the political and military power, i.e. influence on the overall global events directly proportional to the level of development. (Piketty, 2015: 389) By the same matrix, economically less developed countries have less impact on international flows.

All the complexity of issues in national economies is multiplied by their involvement in the international economy. Based on that we talk about international economic relations that are established by way of the international mobility of labor, goods, services and capital. All countries are trying to increase their participation in the exchange with others in the social product, so that they link the total development to mutual economic relations. This process strengthens the international division of labor and integration into international economic flows based on the comparative advantages of national economies. From the time of dissolution of the colonial system, contemporary international economic relations are visibly burdened by the conflict between former colonizers and newly liberated countries. This basic relationship is largely preserved to this day in the form of what we call neo-colonialism. It is believed that the main reason for the growing gap between the developed (North) and developing countries (South) lies in the structure of their commodity production and exchange.

The global status of international economic relations is therefore a generator of tension in itself. Besides that, we must bear in mind numerous concrete actions that belong to the order of means whose common purpose can be formulated as the use of force in the field of economic relations. The policy of force cannot be limited to the use of military force because the very disproportion in the economic strength of the state provides countless opportunities for the imposition of will of the stronger to others. Coercion, pressure and blackmail through economic measures are more and more common forms of power politics in contemporary international relations. All these procedures (coercion, pressure and blackmail) are implemented by using the same means which normally serve as a useful guidance to national economies and international economic relations such as tariffs, quantitative restrictions on foreign trade (import quota system and the system of permits), qualitative foreign trade restrictions, the ban import, export bans, penetration to foreign markets, economic aid and others. In other words, states normally use those means for establishing economic relations with one another. 
The level of scientific and technological (ST) development is an important moment in the analysis made for the positioning of a specific country. The second half of the twentieth century is known for its so-called scientific quantum leap that leads to the dynamic technological development. Regardless of the fact that ultimately technology by itself cannot do anything without science, it is moving forward at such a pace that it often act as an accelerator in relation to science. By its essence, ST development has a significant impact on the international position of a country due to the overall impact on all the factors, which determine the international position. The role of the ST factor in international economic relations is significant because it can decisively influence the positioning of national economy in the international economy. Namely, economic competitiveness is largely determined by the level of technology and skillfulness of labor to utilize its capacity, as well as to create new ST solutions.

Most small and medium-sized countries are forced to instigate their technological development based on technology transfer. By itself, the transfer means strengthening the interdependence of international entities and underpinning integration processes in the world. It is useful for both underdeveloped and developed countries. However, in the modern world one of the main determinants of which is policy from a position of force it is realistic to expect that a provider of technology should try to use its financial and other edges, in order to further improve its already superior position in relation to the customer. Often in international relations, the use of economic power through the abovedescribed mechanism is more effective than military force to realize projects of domination.

Although science and technology group of factors must be denied full autonomy, their great impact on the overall processes of life of the international community, especially on the international position of any country cannot stay unnoticed. The level of ST development is determined by the cumulative capacity of the economy, which leads to the explanation of the international position in relation to other participants in international economic relations. Economic conditions and the level of development can help us analyze the indicators related to the following elements: standard of living, quality of life arising from infrastructure conditions, the status of the health care system, environmental conditions, diet quality and stability of the community. 


\subsection{Food security}

When we talk about food security, two aspects should be taken into account: quantitative (availability of any food source) and qualitative (nutritional structure of food in use). Surely, the security of food cannot be well analyzed without the knowledge about other aspects of security (the areas covered by the concept of human security). Very important indicator of food security is a percentage of earned wages that spent on food. In developed areas, less is being spent on meeting basic biological needs. Lower standard of living also means poorer quality in the structure of food or inadequate nutritional composition.

Economy standard affects the quality of nutrition in relation to the availability of funds for the purchase of appropriate amount of food and its structure. The level of corruption that may be associated with the state of the political system determines the quality of the foods and their safety. In the food manufacturing process starting from breeding plants and animals, through their processing to distribution appropriate standards must be complied with. If the employees working in the system are unhappy with their system status or there is no proper control of their work they are prone to corrupt behavior. All aspects of quality of life may be affected due to that including the health of citizens. Entering the unsafe food in the distribution channels can affect the sustainability of the community in a longer period. An unhealthy diet leads to metabolic disorders burdening the health care system and may lead to depopulation.

\subsection{Health security}

Health security in HS concept shows all the complexity of evaluating the security status of the citizens who live in a certain area. The health care system of poor communities that is otherwise in poor condition due to the little funds available is under pressure due to poor diet. Here we can mention the quality level of education that also depends on economic conditions and is reflected on the health of the population because of the lack of awareness among citizens about the importance of healthy eating and maintaining personal hygiene. The lack of sexual education can manifest itself through an increased number of adolescent pregnancies, which endanger not only the health, but also the lives of girls who are often the victims of improperly performed abortions. 
Security of health, which is directly linked to the quality of the food, affects the natural population growth, fertility rate, life expectancy and many other aspects. However, the health of the population does not depend solely on habits and quality of food, a lot depends on the state of the health system. If the system is in poor condition then problems arise such as increased infant and maternal mortality. Inadequate vaccination and immunization could increase mortality from diseases that are eradicated in developed countries.

\subsection{Environmental security}

Environmental conditions in an area depend mainly on the level of economic development. Developed countries have more opportunities and resources to commit themselves to preserving the environment. In addition to the utilization of new generation technology solutions that are more environment friendly, more is invested in sources of pollution purification systems. Through the system of education, the citizens are supposed to learn about the benefits of living in a healthy environment and the need to preserve it. The issue of ecology awareness and the status of the surroundings in an area is a global phenomenon because the planet is a unique ecological system. All pollutants affect the quality of life and the consequences of their activities accumulate on global level. Consequently, environmental problems cannot be solved partially on the level of individual countries.

Natural environment is very complex to analyze, here we can only grasp a part of it significant for the international positioning of states. We shall limit ourselves to the natural resources such as ores, water flows and forests. Countries rich in ores may have a competitive edge in the international market due to this fact. However, irrational exploitation and the use of dirty technologies could lead to the devastation of the natural environment and endanger the lives and health of the population rather than contribute to raising its standards. The richness of waters could also be an advantage in relation to other countries, however, due to the poorly designed water regulating systems climate change may ensue, endangering the lives and property of the citizens who live in the grip of waterways so that the advantage turns into a disadvantage. Attitude towards forests can also be counterproductive. Forests, as the buffer between the atmosphere and the lithosphere, take the most important place among the types of vegetation in the transformation of precipitation, flow of air masses and the impact on neighboring regions. 
They have a decisive influence on the formation of climate, terrain, water cycle and the exchange of gases in the atmosphere. Unplanned deforestation may cause flash floods, erosion and desertification.

\subsection{Personal security}

It is difficult to separate personal security from community security issues. Security of a citizen creates preconditions for the realization of security of a wider collectivity. In this context, out of the observed phenomena it is difficult to demarcate what should be considered individual security, and what is in the area of community security. As an example, the issue of domestic violence can be construed as a problem of community security and at the same time, it undermines the rights at the individual level. Because of the effects suffered by a greater number of family members, family, and the wider environment (e.g. building occupants) domestic violence is certainly a problem of community. The situation is similar with the quality of housing.

Often in classical approaches based on the concept of state security it is often presumed that the security of citizens necessarily results from the security of territory and the institutions under whose control the said territory is. Unfortunately, in practice it turns out that even in the circumstances of complete protection of the (system) institutions and territory all the citizens are not protected in their daily activities. The discrepancy between the security of the system and territory, and the citizens who live in the given area is increasingly coming to the fore with the globalization of human activities.

The life of citizens in poor parts of the city, which is a symbol of development of the capitalist world, can be threatened by activities of local gangs and corrupt officials. At the same time, the state is not threatened from the outside and by classical security standards; it is given the status of a secure state.

Although personal security presumes an objective situation, in which there is no threatening elements to the people at the individual level it is inconceivable without subjective experience of security, i.e. a state in which citizens are not under the pressure of risk of any adverse event. One of the key factors affecting the personal security is crime and all the side effects of its existence. In addition to crime, other factors also significantly affect the state of personal security of citizens, such as the state of interethnic relations, transportation infrastructure and traffic culture. 


\subsection{Community Security}

Population is a constitutive element of the state. It is people who permanently reside on the territory of a state and that fact has its military and political repercussions. It should be noted that the human factor being one of those elements that determine the development and sustainability of the community is recruited from population.

Each state has a certain number of residents who belong to it. The record of this is a quantitative characteristic of the population. The number of population is considered a primary indicator in all attempts of measuring power, political and military among others. The figures show that the population of individual countries ranges from a few hundred thousand or even tens of thousands (San Marino, Liechtenstein), to more than a billion (China and India). In addition to absolute number, trends in population movement are significant to the international position of a country particularly in view of the times to come. Population growth can be perceived through two segments. The first one is called natural. It includes information about the number of live births per 1,000 populations (fertility), the number of deaths compared to the same base (mortality) and the resultant of these two components - the rate of natural increase (birth rate). The second segment, mechanical movement (migration), includes emigration and immigration.

Natural population migrations lead to the conclusion that some states are young and promising, while others are not. In these assessments, among other things, the fact is included that in those supposedly young and promising countries the ratio: fit-to-work people relative to the part of the population which does not fall into that category is much more favorable than in others. It is in a way linked with the issues of international status, because the issues of estimating the final effects of population movement trends (migrations, depopulation) are security-relevant.

The social structure of the population in a state presupposes the existence of classes and strata as separate segments to which its residents belong (with the corresponding awareness) regarding their position in social production and distribution. Any attempted classification on this basis today confronts the problem of identity. This is due to the fact that, unlike the socio-economic formations belonging to the distant past, where it was obvious who belongs to which class, the class divisions in modern societies is very difficult to discern. Despite socialism as part of the system, contemporary China is almost abreast 
with its ideological opponents in terms of social structure. The dilemma regarding the relevance of the class factor for international relations in general, and especially for the international position of a country increases the number of the already mentioned. It could be said that a certain influence is undeniable, but there is no grounds to attach any greater significance to it. Current changes in the world increasingly underpin the views expressed here on this issue.

National structure is one more essential characteristic of the population relevant for the assessment of the situation in a particular area. Each society is nationally structured in a different way, but belongs to one of three types of state established according to the following criteria: one nation - one state; one nation - more than one states, and more than one nation - one state. None of the three has any advantage a priori at the international level. However, nationally complex states are particularly exposed to the temptation of constantly proving their advantage or disadvantage of such a composition. In such states, as well as in those considered nationally homogeneous according to the previous criteria, there can be members of peoples who have their own state elsewhere. They are national minorities. Issues related to the status of these groups of population are not yet resolved in a manner commonly accepted in international relations. Due to that fact, sporadic solutions of the status of national minorities range from establishing full equality with the domicile nation to a total denial of their existence. The latter part of the way of treating the minorities, the one with the negative sign, often generates conflicts of various intensity in international relations. Because of that, the national minorities are an important factor for generating the international position of every country that has them.

\subsection{Political security}

Political security entails all the factors pertaining to political system, institutions of the system, democratic responsibility of the structure in power and rule of law. The basic presumption of democratic legitimacy of the system is derived from functioning of the political parties and the system of elections. However, in order for the system to really be in the service of interests of the citizens, all its segments must be in harmony with and under control of the parliament as the supreme representative of the citizens' interests. Legislative, judicial and executive power must be in the function of realization and protection of citizens' interests at all times. Security system is no exception in this context. Armed forces, the military and the police, intelligence and counter intelligence 


\section{Securitity}

services are very probably alienated centers of power unless they are under parliamentary control. Therefore, the civil, parliamentary control of armed forces and other organized factors of force are considered an outstanding democratic achievement in the contemporary international community.

States as subjects of international relations are mutually very different: by the level of development, the status they are in and by the orientation towards the future. Definitely, there are differences between the parts within each one of them. However, from the standpoint of our topic this is less significant. It is inevitable that in relation to the aforementioned objective differences and international problems that arise from them there are different views and approaches to solving them. Ideology is one of the means of articulating these different approaches. That is why we can say that ideology encompasses those political ideas with which their holders defend the existing state as being the best possible and justify the relationships established by the group to which they belong (class, layer, society as a whole). This indicates that irrationality is a key determinant of ideology. Therefore, the image of reality as seen through an ideological prism of more or less distorted. ${ }^{3}$

Neither Ideology, nor religion can be tagged either positively or negatively with respect to their impact on international state of affairs in the sphere of the political or military. Any attempt of this kind inevitably ends up on the existing circumstances. This is because even a progressive ideology, created by the process of revolutionary change in a society, can become (becomes) retrograde. A striking example of this ideological transformation, based on the "national narcissism" is chauvinism. The occurrence of similar sociologicalpsychological structure is nationalism. However, nationalism is not necessarily a negative determination with respect to another nation. Chauvinism refers to an exclusive and demeaning attitude of members of one nation towards others who are different. This phenomenon in international relations provokes constant tension; therefore, it should always be taken into account in when assessing the international position of a state.

It is necessary to make a distinction between patriotism and chauvinism, although both phenomena may be based on love for one's own nation. However, while in the case of

\footnotetext{
${ }^{3}$ If political systems are determined by their dominant ideological matrix: in that case the current hegemonic ideology of neoliberalism determines the emergence of oligarchic governance, most obviously in the US. (Gilens \& Page)
} 


\section{Securiatity}

chauvinism this love turns into hatred towards others, patriotism is expressed by loyalty to the positive values of one's own nation and society, along with full tolerance and respect for others. From the standpoint of the international position of a state, there exists a significant risk of manipulating people's patriotic feelings by self-appointed leaders, because it is a manifold tested means of triggering instability in international relations.

Political system is "institutionalized form and manner in which the relationship between public authorities and society is determined and regulated". More specifically and detailed, we understand political system as a system of institutionalized political power holders in a community: the way of their constitution, organization and action, on the one hand, and the set of institutions and relations through which an organized link between the political power holders and social powers in whose name they govern is established, on the other." (Pasic, 1974: 72). However, often, or usually, political systems are determined by the dominant ideological matrix that is characteristic for a particular community. As a rule, more democracy in the country means a greater contribution to the preservation of international peace and security, and cooperation that is more international. This state activity in the international field is called foreign policy.

\section{CONCLUSION}

When talking about the international position of a country in terms of globalization, the consideration of only classical statistical indicators is not enough. It is necessary to put them into the context of current geopolitical circumstances. A qualitative analysis of the internal conditions is also necessary. ${ }^{4}$ Quantifying only the factors of force does not give a real picture without the analysis of economic and political conditions in the country, but also their global context. Multivariate analysis based on the seven-dimensional matrix of the concept of human security provides a proper analytical framework for the quantitative analysis to cover the largest number of relevant factors influencing the international position of countries.

The total social power of each state invariably has a component that we call the apparatus of coercion and force. This component is inherent to the state as a social and

\footnotetext{
${ }^{4}$ It also applies to statistics relevant to human security, such as ranking of corruption, which is defined in such a way as to exclude tax avoidance and other 'legal' felonies committed by financial institutions and multinationals, and supported by state authorities.
} 
political body. Hence, the resulting definition of the state as an apparatus of public authority, which has the monopoly of organized coercion. This coercion is directed towards its own subjects and/or to the space beyond its borders and is a sign of its status. In this context, the army and the police are always an important and sometimes decisive factor of the political process. In contemporary international relations, independence of the military factor is not as blatantly expressed as in previous periods. This factor is usually in close connection with the political factor. This is decisively influenced by the fact that the nuclear capacity of great powers is such that they can destroy the world many times over. The commitment to strengthen the political at the expense of the military passes through various stages. They include inter alia the relative independence of these two factors or their firm link-up, regardless of whether the former absorbs the latter or vice versa. Therefore, the terms "political" and "military" with its linguistic modalities are among the most frequent ones in the science of international relations. The strongest and unambiguous link between the political and military spheres in history is achieved through the phenomenon of war.

In view of the destructive potential expressed through the amount of conventional, nuclear and other types of weapons, the demonstration of power through its rawest form of warfare is less likely among the great powers. Even in the relations between the great powers and small countries, the positive and negative aspects of a potential conflict are always taken into account. Therefore, today, when we talk about the international position of the state, we do not ignore the elements of hard power, but more and more attention is paid to the so-called soft power.

The ability to defend own interests and carry out own programs depends on the power of the institutions to properly mobilize the existing resources to realize them in their full capacity. Given that the global stage is a limited space in which the interests of all the participants are opposed, the communities that succeed in homogenizing human resources for the realization of their interests make the best of it. Normally, when designing strategies, wider circumstances influencing the course of events must be taken into account. For example, the level of development of economic entities does not mean a thing without the human factor and the political system that will articulate the interests of the community to the best of their realization. However, if it the existing circumstances on the international market and the conditions for the placement and 
exchange of manufactured goods are not taken into account, not even the best development strategy yields appropriate results.

The position of a subject of international relations, regarded as a kind of system, contains, as many sub-systems as there are relevant groups of factors that influence the securing of a comprehensive international position. One subsystem demarcation from another is not advantageous. Their contents overlap more or less, creating unions and cross sections, both in time and in space. The international position is certainly one such complexity, because it connects many extremely important elements of social and economic life.

International relations are packed with a variety of contacts, longer or shorter, and relationships, more or less strong, between a number of entities that establish them and maintain. If we accept the view that the state is the main actor in international relations from whose subjectivity directly or indirectly the status of other international entities results, then inevitably, it must be the focus of the debate on the state of affairs in the international community.

Comprehensive analyses such as this one, which is based on the concept of human security can contribute in a favorable set of circumstances not only to understanding the current situation but also to the creation of a new international system more adequate to the current situation and solving the problems of the modern world.

Taking into account the known determinants of the international position of the state and starting from them, we can say that the international position of a country indicates whether there are military and political conditions for the expression of genuine interests of the state entity in question. They are independence and territorial integrity without which there is no free construction of a society tailored by the measure of its creators. It is the process of determining the defense identity of a country, stopped at some point of a positive or negative trend of certain intensity. The "defense Identity" has a key place in the real cognition of the international position and any analysis of the international situation needs to start from it. One cannot speak of a favorable international position of a country that does not develop its defense capability and potential. On the other hand, a good offensive performance is not enough as a sign of an auspicious military-political position. Therefore, it can be said that the adverse international position is a consequence of disproportion between the offensive and defensive capabilities in which the former are 
overemphasized at the expense of the latter. In addition, the favorable international position is established by an optimal combination of factors that determine it. They should be of as good a quality and quantity as possible. It also can be considered that the international position is a resultant of a polygon of forces, which is determined by the direction, meaning and size of the components adequate to the effect of its factors.

The concept of human security is primarily focused on the analysis of factors affecting the quality of life of individuals as local community members, citizens of certain countries, as well as global citizens. The fact is that with globalization the state loses many of its prerogatives that used to affect the decrease of power of influencing the happenings on the international scene. However, despite that, state institutions are still the only ones with a real power of performing a practical action in furtherance of the interests of people living on its territory. The realization of citizens' interests depends not only on the willingness of local institutions that are working in their interest, but also of the international position of a particular state. The set of circumstances on the international scene determines the power of action of the institutions. Here we come to the key determinant of our work: institutions of the system contribute to the quality of life of the citizens to the extent the international circumstances and the position of the state enables them to do that

\section{LITERATURE}

1. Aćimović, Ljubivoje (1987), Nauka o međunarodnim odnosima: Teorije i istraživački pravci, Naučna knjiga, Beograd.

2. Chandler David and Hynek Nik (2010), Critical Perspectives on Human Security Rethinking Emancipation and Power in International Relations, Routledge Taylor \& Francis Group, London and New York.

3. Dimitrijević, Vojin and Stojanović, Radoslav (1979), Međunarodni odnosi, Nolit, Beograd.

4. Đorđević, Ivica (2013), LJUDSKA BEZBEDNOST - globalni kontekst i primena u Srbiji, Dosije - Institut za uporedno pravo, Beograd.

5. Gavranov, Velibor and Stojković, Momir (1972), Međunarodni odnosi i spoljna politika Jugoslavije, Savremena administracija, Beograd.

6. Gilens, Martin and Page I. Benjamin (2014): "Testing Theories of American Politics: Elites, Interest Groups, and Average Citizens", in: Perspectives on 
Politics. Vol. 12, No.03. American Political Science Association, Cambridge. pp 564 $-581$

7. Herz, John (1951), Political Realism and Political Idealism, The University of Chicago Press, Chicago.

8. Mijalkovski, Milan and Đorđević, Ivica (2010), Neuhvatljivost nacionalne moći, Službeni Glasnik, Beograd.

9. Morgenthau, Hans (1967), Politics Among Nations, Alfred Knopf, New York.

10. Nef, Jorge (1999), HUMAN SECURITY AND MUTUAL VULNERABILITY The Global Political Economy of Development and Underdevelopment, International Development Research Centre, Ottawa.

11. OUP (1989), Oxford Advanced Learner's Dictionary, Oxford University Press, Oxford.

12. Owens, Patricia and Baylis, John and Steve, Smith (2013), The Globalization of World Politics: An Introduction to International Relations, Oxford University Press, 0xford.

13. Pašić, Najdan (1974), Klase i politika, Rad, Beograd.

14. Scott, James C. (1998), Seeinglike a State How Certain Schemes to Improve the Human Condition Have Failed, Yale University Press, New Haven and London.

15. Schwarzenberger, Georg (1965), Power Politics: A Study of World Politics, London.

16. Stojanović, Radoslav (1982), Sila i moć u međunarodnim odnosima, Radnička Štampa, Beograd.

17. UNDP (1994): Human Development Report, Oxford University Press, New York Oxford. 